\title{
Tobacco Institute lobbying at the state and local levels of government in the 1990s
}

\author{
C P Morley, K M Cummings, A Hyland, G A Giovino, J K Horan
}

Tobacco Control 2002; 11 (Suppl I):i102-i 109

See end of article for authors' affiliations

Correspondence to K Michael Cummings, PhD $\mathrm{MPH}$, Department of Cancer Prevention, Epidemiology \& Biostatistics, Roswell Park Cancer Institute, Elm and Carlton Streets, Buffalo, New York 14263, USA; Michael.Cummings@ Roswellpark.org
Objective: To describe variation in Tobacco Institute (TI) lobbying expenditures across states and test whether these expenditures vary in relationship to measures of tobacco control activity at the state level. Independent variable: Data for this study came from the TI's State Activities Division (SAD) annual budgets for the years 1991-97, excluding 1993. These data include budgetary information pertaining to state and local lobbying activity and special projects reported by state.

Dependent variables: The following measures of state tobacco control activity during the period 1991 to 1997 were considered: (1) American Stop Smoking Intervention Study (ASSIST) funding; (2) voter initiatives to raise cigarette taxes; (3) cigarette excise tax level; (4) workplace smoking restrictions; (5) the intensification of smoke-free air laws covering private worksites, government worksites, and restaurants; (6) the intensification of strength of sales to minors laws; (7) the intensification of strength of laws that punish minors for possessing, purchasing, and/or using cigarettes; (8) state status as a major grower of tobacco; (9) partisan control of state government, 1996; and (10) an overall composite index reflecting a state's strength of tobacco control, combining cigarette prices with workplace and home smoking bans.

Results: The overall annual budget for the TI declined steadily during the 1990s, from $\$ 47.7$ million in 1991 to $\$ 28.1$ million by 1996 . The proportion of the TI's budget allocated to the SAD remained relatively stable at about $30 \%$. TI expenditures for lobbyists were highest in California where tobacco control activity has been strong for the past decade. We found significant associations between TI SAD expenditures and cigarette excise tax levels, the status of a state as a recipient of federal ASSIST funds, and changes in the strength of statewide laws that penalise minors for possessing, purchasing, and/or using cigarettes. We found little or no association between state and local lobbying budgets of the $\mathrm{TI}$ and changes in statewide smoke-free air laws, although we did find evidence of TI special project expenditures earmarked to specific states and localities to resist clean indoor air legislation/regulations (that is, Maryland and New York City). We found no significant correlation between TI lobbying expenditures and sales to minors' laws, status as a major producer of tobacco, or partisan control of state government.

Conclusions: The findings from this study support the hypothesis that in the 1990s tobacco control activities such as raising cigarette excise taxes and participation in ASSIST attracted TI resources to undermine these efforts.
$\mathrm{T}$ he marketing (that is, the advertising, pricing, product design, packaging, and distribution) of tobacco products is clearly affected by the legislative and regulatory environment in which it takes place. The tobacco industry seeks to manage this regulatory environment and has utilised a variety of strategies to oppose enactment of tobacco control legislation at the state and local levels of government. ${ }^{1-6}$ Goldstein and Bearman recently documented tobacco industry lobbyist activity in different states. ${ }^{4}$ This study indicated that although there were tobacco lobbyists working in all states, there was variability in the number of lobbyists per state (mean number per state 9, range 2-25). Goldstein and Bearman also noted that the rules for documenting lobbying expenses vary across states making meaningful comparisons difficult.

In recent years, a vast amount of new information documenting the lobbying activity of the tobacco industry at the state and local levels of government has become available through the release of formerly secret industry documents obtained through litigation. Malone and Balbach have described various sources of these documents. ${ }^{7}$ Givel and Glantz have recently utilised industry documents to explore the strategies employed by the industry to undermine tobacco control measures at the state and local level, and reported the lobbying expenditures listed in the Tobacco Institute's (TI) 1997 annual budget. ${ }^{1}$ They concluded the tobacco lobby is a powerful influence in state legislatures.
The TI was formed in 1958 as an industry trade organisation, charged with communicating the industry's positions on health and economic issues to the general public (that is, public relations) and to federal, state, and local governments (that is, lobbying and committee testimony) in the USA. A committee consisting of all major and several smaller USA tobacco manufacturers governed the TI, and funded its budget. The TI specifically did not engage in the sale, manufacture, marketing, or distribution of tobacco products, and ostensibly did not fund health related tobacco research. The TI was disbanded in 1998. We have acquired the budgets of the TI from the industry hosted websites linked through http://www.tobaccoresolution.com.

Ideally, we would like to have had access to each state's records of reported lobbying expenditures. However, this is not possible because of variation between reporting requirements and accessibility to data between states, and to interstate variation in how lobbying expenditures are reported over time. Given the inconsistent reporting requirements of the states, we believe the TI budgets represent a clearer view into the historical spending habits and political priorities of that organisation over time. Regardless of what and how it would have to

Abbreviations: ASSIST, American Stop Smoking Intervention Study; NSA, National Smokers' Alliance; PPU, possessing, purchase and/or use; SAD, State Activities Division; SOTC, strength of tobacco control; TI, Tobacco Institute 
report publicly from state to state, it stands to reason that the TI would have tracked its own expenditures in an internally consistent manner.

In this paper, we present information extracted from TI documents showing planned lobbying and other expenditures by state for the years 1991 to 1997, excluding 1993. Appropriate data were unavailable for 1993. This represents TI activity within most of the past decade, up to the point at which consistent data retrieval $(\geqslant 1998)$ becomes impossible-that is, the TI budgets that are available for 1998 are limited. It is important to note that spending by the TI does not represent the totality of industry expenditures at the state and local levels of government. Each cigarette manufacturer had personnel engaged in political activity, and it is recognised that a great deal of money flowed through third party organisations other than the TI. However, specific budgetary data for these organisations are sparse, at best. The availability of the TI budgets provides a unique opportunity for examining variation in TI expenditures across states over time. Two questions guided this study: (1) Did TI spending vary significantly by locale over time? (2) If so, what factors influenced variation? We reasoned that variation in TI lobbying expenditures over time and between states would provide clues about what the tobacco industry perceived to be its greatest threats to continued growth.

\section{METHODS \\ Document retrieval: TI budgets}

To locate information on TI expenditures by state, it was necessary to conduct a comprehensive search of all of the tobacco industry document websites. Search terms and strings were entered into the search fields of each document database linked through http://www.tobaccoresolution.com, and the resulting citations retrieved were examined for relevance.

Data for this study were extracted from specific accounting lines within TI budgets for the years 1991 to 1997 . We were able to locate 11 documents, ${ }^{8-18}$ representing components of annual budgets for the TI for the years 1991-97. For 1993, we could not locate budgetary data for the State Activities Division (SAD) broken down by state in a way that was consistent with other years. In many cases, we identified duplicate documents from the different industry websites. The selection of the data to be extracted from the TI budgets followed three criteria:

- The data had to relate to activities intended to undermine state or local tobacco control efforts

- The data had to be itemised by state

- The data had to be internally consistent (that is, be categorised into cost centres and accounts that were consistently used from year to year).

The TI was organised into different departments, and the SAD was responsible for lobbying and legislative affairs at the state and local levels of government. The budgets were organised by department (with an assigned cost centre number), and within each department, account names and numbers indicated types of expenditure. Within the sections of the annual budgets that cover this division (specifically cost centre 1401), certain accounts were itemised by expenditure per state within each account. Within the SAD, there were three accounts that were consistently reported on a year-to-year basis through the analysis period (1991-97), and that disaggregated the data by state: state level lobbyists ("lobbying consultants"), local lobbyists ("consultants"), and "special projects". Other accounts were also identified containing data disaggregated by state, such as honoraria (that is, speakers' fees, etc), contributions to state tobacco wholesaler organisations, state campaigns, and local campaigns. However, the most consistent year-to-year data exist in the first three categories mentioned. We did find evidence that the TI may not have consistently funded wholesaler organisations on an annual basis, which could account for the year-to-year variation observed for this budget category. ${ }^{19} 20$

A database was constructed to show expenditures for a given state for each year from 1991 to 1997, with the exception of 1993. For the purposes of this paper, we have chosen to limit our analysis of TI spending to budgeted expenditures for state and local lobbyists and special projects (1991-97, excluding 1993). For the years 1995, 1996, and 1997, data were also available for both state tobacco wholesaler organisation funding and for "national/state organisations" (organisations not directly associated with tobacco in name or mission). We found a strong correlation (Spearman rank correlation 0.40, $\mathrm{p}<0.01$ ) between TI lobby expenditures and organisational expenditures, suggesting that organisational expenditures followed lobbying expenditures. Since we observed relatively little variation in the organisational expenditures budgeted for states between 1995 and 1997, we have chosen to limit our analysis of TI spending to budgeted expenditures for state and local lobbyists and special projects.

\section{State tobacco control activity}

The following measures of state tobacco control activity during the period 1991 to 1997 were considered in this paper: (1) American Stop Smoking Intervention Study (ASSIST) funding; (2) voter initiatives to raise cigarette taxes; (3) cigarette excise tax level; (4) workplace smoking restrictions; (5) the intensification of smoke-free air laws covering private worksites, government worksites, and restaurants; (6) the intensification of strength of sales to minors laws; (7) the intensification of strength of laws that punish minors for possessing, purchasing, and/or using cigarettes; (8) state status as a major grower of tobacco; (9) partisan control of state government, 1996; and (10) an overall initial outcomes index, combining cigarette prices with workplace and home smoking bans. Each of these measures is described below.

\section{ASSIST funding}

Seventeen states applied for and received approximately \$1 million annually in funding from the National Cancer Institute between 1991 and 1999 to support development of state based tobacco control programmes to prevent and reduce tobacco use. This programme, known as ASSIST (American Stop Smoking Intervention Study), emphasised enactment of policy based approaches to strengthen tobacco control laws aimed toward discouraging smoking (that is, cigarette taxes, clean indoor air laws, etc). ${ }^{21}$ For the purposes of analysis, ASSIST states were coded " 1 ", while non-ASSIST states were coded " 0 ".

\section{Voter initiatives}

During the 1990s California, Arizona, Massachusetts, and Oregon enacted or had in place voter initiated cigarette tax increases, with millions of dollars raised by these taxes intended for tobacco control programming. The status of these states as "tax initiative" states, as opposed to "non-initiative" states, was used as a grouping variable. The four states that enacted cigarette excise tax legislation via the voter initiative process (California, Arizona, Massachusetts, Oregon), ${ }^{52-24}$ were coded " 1 ", while all other states were coded " 0 ". It was not expected that lobbyist expenditures would be significantly associated with the initiative process itself, since the initiative process takes place outside of the legislature. It was hypothesised that lobbying expenditures would be associated with successful tax initiative states, however, since lobbyists could potentially influence the appropriations processes that follow successful tax increases. 


\section{Cigarette excise taxes}

State cigarette excise tax rates were extracted from TI's Tax burden on tobacco. ${ }^{25}$ Cigarette excise taxes expressed in cents per pack were collected for each state for 1991 and 1997. We also computed a simple difference in tax rate between 1991 and 1997 so that states could be ranked on the basis of an increase in excise tax rate.

\section{Workplace smoking restrictions}

The percentage of workers in a state employed in smoke-free workplaces was measured using data collected from the 1995-96 Current Population Survey Tobacco Use Supplement. This measure reports the percentage of indoor workers covered by a smoke-free workplace policy, defined as "smoking not permitted in public and common areas of the worksite or in the work areas." The data from this survey are reported by state in a National Cancer Institute monograph. ${ }^{26}$

\section{Intensification of smoke-free air laws in private and government worksites, and restaurants}

Giovino and colleagues ${ }^{27}$ have used reports from the American Lung Association ${ }^{28}$ and the Centers for Disease Control and Prevention ${ }^{29}$ to classify state laws restricting smoking in private worksites, government worksites, and restaurants for the years 1991 through 1997. Individual contacts of researchers with state governments were used to resolve any discrepancies. For each of these locations, each state received a score of 0 if no restrictions were required, 1 if restrictions were required (without separate ventilation), 2 if smoking was restricted to separately ventilated areas, and 3 if smoking was prohibited indoors. The scores for each location were totalled for each state in each year (theoretical range 0-9). We then subtracted the total for 1991 from 1997, using the difference score as an indicator of the intensification of restrictions.

\section{Intensification of laws restricting sales of tobacco products} to minors

The rating system for states on laws that penalise vendors for selling tobacco to minors, as developed by Alciati and colleagues, ${ }^{30}$ was utilised as an indicator of state activity levels in youth access prevention. Each state was scored on nine criteria pertaining to their youth access laws for the years 1993 to 1996. The nine criteria evaluated included:

- minimum age for purchase of tobacco products of 18 , including a requirement for in-store signage indicating minimum age

- prohibition of cigarette sales if not in a sealed package

- prohibition of sale without intervention by a sales clerk

- photo identification requirement for purchasers who appear under 21 years of age

- ban on all tobacco sales through vending machines

- ban on free distribution of tobacco samples, coupons for free samples, and rebates

- graduated penalties for all youth access laws, plus possibility of suspension or revocation of retail license for repeated sales to minors

- random, unannounced inspections of retailers as part of enforcement mechanism, with use of underage buyers

- establishment of a statewide enforcement authority for sales.

Ratings for six of the nine categories were assigned from 0 (no effective provision) to 4 (meets target), and three provisions (minimum age, photo identification, free distribution) were scored from 0 to 5 (exceeds target). Alciati and colleagues used the following rating system: $5=$ exceeds target; $4=$ meets target; $3=$ meets $\sim 75 \%$ of target; $2=$ meets $\sim 50 \%$ target; $1=$ meets $\sim 25 \%$ target; $0=$ no effective provision.
States were ranked based on the change in score over the time period measured. This was calculated to depict level of activity within a state on youth access issues. The change in score from 1993 to 1996 was calculated as an indicator of the intensification of restrictions.

Intensification of laws penalising minors for possessing, purchasing, and/or using tobacco products

Giovino and colleagues ${ }^{27}$ have used reports from the American Lung Association, ${ }^{28}$ the Centers for Disease Control and Prevention, ${ }^{29}$ and state governments to classify state laws penalising minors for possessing, purchasing and/or using (PPU) cigarettes from 1991 through 1997. Individual contacts of researchers with state governments were used to resolve any discrepancies. A statewide PPU (possession, purchase, and use) law index (range 0-3) was calculated by summing the number of these laws in place in a state in any given year. We totaled the codes for each state on their PPU laws, and subtracted the total for 1991 from 1997, using the difference score as an indicator of the intensification of restrictions.

\section{State status as a major grower of tobacco}

A state's involvement in tobacco growing was measured using data reported by the US Department of Agriculture. ${ }^{31}$ These data reveal that during the 1990s, there were six states heavily involved in tobacco growing and/or manufacturing. These six states include in order of importance: North Carolina, Kentucky, Tennessee, South Carolina, Virginia, and Georgia. Each of these states had average cash receipts from tobacco in excess of $\$ 100$ million (the next tier begins at Ohio, with $\$ 35$ million). States heavily involved in growing tobacco (top six average cash receipts for tobacco) were coded " 1 " while all others were coded " 0 ".

Partisan control of state government, 1996

Information on the partisan composition of each states' legislature was obtained from a recent paper by Luke and colleagues $^{32}$ and the National Conference of State Legislatures (NCSL). ${ }^{33}$ These data were only available for 1996. Using these data we created a dichotomous measure to reflect the partisan balance of power (that is, Republican or Democrat) between the governor's office and each bicameral legislative house for each state for 1996. Nebraska has a unicameral legislature. This state had both a Democratic governor, and a majority of state senators who were Democrats in 1996. Therefore, Nebraska was labelled as a "Democratic" state, in keeping with the dichotomous coding structure. Predominantly Republican states were labelled " 0 " and predominantly Democratic states were labelled " 1 ".

Composite ranking of a state's strength of tobacco control A recent paper by Gilpin and colleagues ${ }^{34}$ constructed a composite index to score states on their strength of tobacco control (SOTC) during the 1980s and 1990s. This standardised index was based upon measures of a state's cigarette price per pack, workplace smoking bans, and home smoking bans. Gilpin and colleagues $^{34}$ demonstrated that the SOTC index score had predictive validity since it was strongly correlated with both adult smoking prevalence $(\mathrm{r}=-0.70)$ and per capita consumption $(r=-0.73)$. We used the SOTC index score for each state and compared it with TI lobbying expenditures.

\section{Data analysis}

TI lobbying expenditures, measured as state and local lobbying and special projects, in a given state for a given year were adjusted for inflation to reflect year 2000 dollars. The adjusted yearly totals for each state were then averaged. There was significant association seen between average lobbying expenditure per state and average state population size $(r=0.78$, $\mathrm{p}<0.000)$. However, we chose not to express TI expenditures 


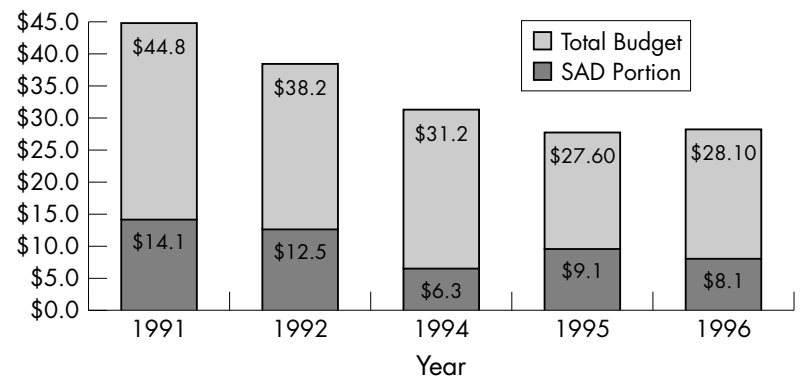

Figure 1 Tobacco Institute budgets with State Activities Division portion of total ( in millions of dollars)

on a per capita basis because the amount of variation in TI expenditures between states was less (that is, 11 -fold difference between the lowest and highest states: \$32 323 in North Dakota to $\$ 366660$ in California) than the amount of variation between states in population size (that is, 66-fold difference in population size between the smallest and largest states: 472463 in Wyoming to 31349879 in California). Larger states like California and New York would shift dramatically in rank if adjusted for population size. However, the text of the TI budgets clearly illustrate that TI budgetary allocations were not based solely on population size. Rather, the TI budgets for special projects appear in many instances to be allocated to states based upon what appears to be specific legislative initiatives on such topics as tobacco taxes and smoke-free air laws. We feel that erasing this increased level of activity by adjusting for population size would not adequately reflect the true level of activity in a given state. The unadjusted average expenditure does a better job of representing level of activity. Additionally, the data extracted only represents approximately $35 \%$ of the SAD budget, itself only a component of TI and industry wide spending. Therefore, we did not have a true picture of total spending per capita by the TI, but rather an indicator of fluctuation in spending temporally and by locale.

Spearman rank correlations were computed to evaluate the association between the average annual (1991-97) TI lobbying expenditures and continuously measured indicators of tobacco control activity for each state (that is, tax rates, tax difference between 1991 and 1997, percentage of employed persons working in a smoke-free workplace in 1995-96, workplace and restaurant smoke-free laws, strength of sales to minors laws, PPU laws, and initial outcomes index). To analyse the relation between the ranks of states on TI expenditures and dichotomously measured indictors of state tobacco control activity (that is, ASSIST funding and voter initiatives), a Mann Whitney U test statistic was computed.

We also evaluated the association between TI spending and a state's involvement in tobacco growing, as well as its political affiliation (that is, Republican $v$ Democrat), to incorporate measures reflecting states' political/economic environment. Since both of these measures were dichotomous variables, we used the Mann Whitney U test statistic to analyse the relation between the ranks of states on TI average lobbying expenditures and indicators of tobacco control activity.

\section{RESULTS}

\section{Descriptive data on TI spending}

As illustrated in fig 1 , the overall annual budget for the TI declined steadily during the 1990s from $\$ 44.8$ million in 1991 to $\$ 28.1$ million by 1996 . With the exception of 1994 , the proportion of the TI's budget allocated to the SAD remained relatively stable at about 30\%. Between 1991 and 1997, the average annual budget for the SAD was \$10.6 million. As illustrated in fig 2, approximately $27 \%$ ( $\$ 2.8$ million) of the SAD budget was allocated to state lobbyists, $3.9 \%$ (\$419 033) to local lobbyists, and 3.8\% (\$404 430) to special projects.

Table 1 provides the average annual expenditures to lobbyists (combining state and local lobbyists categories with the "special projects" category). State rankings were fairly stable over time (data not shown). California and New York were ranked highest in average TI spending. There were a few states where the rankings on TI spending did change greatly between 1991 and 1997. For example, between 1992 and 1994, Arizona's ranking on TI spending greatly increased from 22 to 2. Arizona's change in ranking on TI lobbying expenditures corresponds with a legislative debate capping funding for the state's anti-tobacco education programme below amounts approved by a voter initiative earmarking cigarette excise taxes to fund the programme. ${ }^{24}$ Maryland's ranking on TI spending increased greatly in 1994 and appears to be largely the result of funding of a special project labeled "Maryland OSHA Project" (\$102 500) and to a second special project labeled "Talbot Co. Initiative" (\$55 000). Subsequent enactment of workplace smoking regulations in Maryland eliminated smoking from most workplaces, including many in the hospitality industry. ${ }^{35}$ Ohio's higher ranking in 1991 and 1992 was influenced by a special project entitled "tax project" (\$35 000/year), corresponding to the time period immediately preceding a 1993 cigarette tax increase of 6 cents per pack. In



Figure 2 Average budget for state and local lobbying and projects within the State Activities Division (SAD)

Accounts (spending categories) within TI/SAD budgets

State lobbyist = "Legislative consultant" (LC)

Local lobbyist = "Consultant" (CO)

Special projects $=$ Special projects $(S P)$

Other SAD categories included state and local campaign contributions and honoraria 
Table 1 Average annual expenditures of Tobacco Institute State Activities Division to state and local lobbyists and special projects, 1991-97

\begin{tabular}{|c|c|}
\hline State* & $\begin{array}{l}\text { Average annual lobbying } \\
\text { expenditures (1991-97t) }\end{array}$ \\
\hline California & $\$ 364092$ \\
\hline New York & $\$ 344562$ \\
\hline Minnesota & $\$ 215997$ \\
\hline Illinois & $\$ 163782$ \\
\hline Pennsylvania & $\$ 137028$ \\
\hline Massachusetts & $\$ 134055$ \\
\hline Texas & $\$ 127895$ \\
\hline Maryland & $\$ 122578$ \\
\hline Washington & $\$ 119477$ \\
\hline Florida & $\$ 118570$ \\
\hline Wisconsin & $\$ 114344$ \\
\hline Ohio & $\$ 111783$ \\
\hline Connecticut & $\$ 108075$ \\
\hline Michigan & $\$ 104734$ \\
\hline Arizona & $\$ 92087$ \\
\hline New Jersey & $\$ 87909$ \\
\hline Hawaii & $\$ 86576$ \\
\hline Colorado & $\$ 85272$ \\
\hline Maine & $\$ 82550$ \\
\hline Missouri & $\$ 80142$ \\
\hline North Carolina & $\$ 76937$ \\
\hline Virginia & $\$ 76889$ \\
\hline Indiana & $\$ 75695$ \\
\hline Louisiana & $\$ 74135$ \\
\hline Utah & $\$ 73812$ \\
\hline lowa & $\$ 69369$ \\
\hline Georgia & $\$ 66839$ \\
\hline Alabama & $\$ 60915$ \\
\hline Tennessee & $\$ 59265$ \\
\hline Alaska & $\$ 57502$ \\
\hline New Mexico & $\$ 56622$ \\
\hline Oregon & $\$ 55530$ \\
\hline Oklahoma & $\$ 53631$ \\
\hline South Carolina & $\$ 52763$ \\
\hline Montana & $\$ 51582$ \\
\hline South Dakota & $\$ 47895$ \\
\hline Nevada & $\$ 45234$ \\
\hline New Hampshire & $\$ 44574$ \\
\hline West Virginia & $\$ 43511$ \\
\hline Kansas & $\$ 43358$ \\
\hline Rhode Island & $\$ 42371$ \\
\hline Wyoming & $\$ 40749$ \\
\hline Kentucky & $\$ 40462$ \\
\hline Idaho & $\$ 39328$ \\
\hline Vermont & $\$ 38155$ \\
\hline Mississippi & $\$ 38052$ \\
\hline Delaware & $\$ 36066$ \\
\hline Nebraska & $\$ 33350$ \\
\hline Arkansas & $\$ 31969$ \\
\hline North Dakota & $\$ 31916$ \\
\hline
\end{tabular}

1995 and 1996, a "Utah Public Relations Program" received $\$ 30000$ in each year, corresponding to the time period immediately preceding a doubling of the state's cigarette tax. Payments to a special project labelled "Washington State Center for Tax Policy" for 1995 and 1996 for \$62 000 coincide with a rapidly escalating cigarette tax in that state.

New York State's number one ranking in lobbying expenditures from 1994-96 is largely due to special projects. In 1994, a special project labelled "New York City OSHA" received $\$ 125000$, and in 1995 a project labelled "New York State Preemption Plan" received \$279 700, and a "New York City Project" received \$165 000. New York's rank in 1996 ahead of California was caused by an absence of local lobbying or special projects allocated to California during this time period. In 1997, a "local monitoring project" is listed as receiving \$75 000 in California, bringing that state back into the highest ranked position on lobbying expenditures. Colorado's strong ranking on TI spending in 1995 appears to coincide with a failed voter initiative campaign to raise cigarette excise taxes to support health education programming. ${ }^{6}$ Colorado, Minnesota, and Washington all appear to have had continuing "ASSIST" special projects from 1995 onward.

\section{TI spending and tobacco control activity at the state level}

Table 2 shows the association between state rankings on TI spending and measures of a State's tobacco control activity. TI lobbying expenditures were associated with different indicators related to cigarette taxes (overall tax rate, ASSIST funding, change in PPU laws, and the SOTC composite index ranking).

Table 2 also shows the association between the ranks of states on TI expenditures, and dichotomously measured indictors of involvement in tobacco growing and political affiliation (that is, Republican $v$ Democratic). No significant association was seen between TI lobbying expenditures and a state's status as a major tobacco grower. However, TI spending was consistently lower in states heavily involved in tobacco growing (top six tobacco growers all fall below average lobbying expenditure (\$87200), and all fall within one standard deviation of lowest average annual expenditure (SD $\$ 67081)$ ). A state's political affiliation was unrelated to TI's lobbying expenditures.

\section{DISCUSSION}

These data suggest that the TI was spending more money in states where tobacco control activity was stronger. TI spending was highest in California where tobacco control activity has been strong for the past decade. TI spending was also found to be consistently higher in states that were active in boosting cigarette taxes during the 1990s (that is, New York, Minnesota, Hawaii, Arizona, Alaska, Illinois). The temporal shift in TI spending observed in some states appears to correlate with efforts to raise and/or earmark cigarette taxes (Arizona 1994, 1995, Colorado 1995, Massachusetts 1991, 1992, Ohio 1991, 1992, Maine 1994) and in states where smoke-free legislation was under consideration. We found evidence of TI special project money being earmarked to projects to oppose indoor smoking restrictions and higher tobacco taxes. Since ASSIST-supported state programmes had as one of their main objectives enactment of smoke-free laws and higher cigarette taxes, it is not surprising that our analysis found that ASSIST states also attracted the greatest lobbying attention from the TI.

Although there is some indication of heightened TI activity to counter legislation/regulations on indoor smoking in states such as Maryland (1995, 1996), Washington (1995), Utah (1996, 1997), and New York (1995), the overall association between lobbying expenditures and statewide measures of indoor smoking restrictions were not significant. The apparent lack of association seen between TI spending and workplace smoking restrictions may reflect the fact that the tobacco industry also relied on third party organisations to oppose indoor smoking laws. ${ }^{36-38}$ This is reflected in the significant association found between change in state smoke free air laws and TI/SAD expenditures to outside organisations (data not shown). Moreover, during the 1990s Philip Morris and RJ Reynolds tobacco companies both had significant lobbying programmes of their own, as did the other manufacturers to a lesser extent. ${ }^{1}$ The decline in the TI's annual budget during the 1990s strongly suggests that tobacco manufacturers began to rely less on the TI to lobby on their behalf. For example, in the early 1990s Philip Morris helped create and financially supported the National Smokers' Alliance (NSA), which worked to aggressively oppose state and local laws limiting 
Table 2 Association between Tobacco Institute state and local lobbying expenditures for 1991-97 and indicators of tobacco control activity

\begin{tabular}{|c|c|}
\hline Indicators of tobacco control activity & $\begin{array}{l}\text { Spearman rank correlation coefficients between the average } \\
\text { TI/SAD lobbying expenditures and indicators of tobacco control } \\
\text { at the state level* }\end{array}$ \\
\hline Cigarette tax rate in 1997 & $0.28, p=0.05$ \\
\hline Difference in tax rate between 1991 and 1997 & $0.10, p=0.49$ \\
\hline Per cent employed in a smoke-free workplace in 1995/96 & $0.24, p=0.10$ \\
\hline Change in smoke-free air laws in private/gov't work sites and restaurants, 1991-1997 & $0.08, p=0.60$ \\
\hline Change in score, sales to minors laws 1993 and 1996 & $-0.01, p=0.96$ \\
\hline Change in youth possession, purchase and use laws, 1991-97 & $0.31, p=0.03$ \\
\hline \multirow[t]{2}{*}{ SOTC composite index } & $0.37, p=0.01$ \\
\hline & $\begin{array}{l}\text { Results of Mann-Whitney } U \text { test comparing average rank of states } \\
\text { on TI/SAD lobbying expenditures by selected characteristics } \dagger\end{array}$ \\
\hline ASSIST funded $(n=17) \vee$ non-ASSIST funded $(n=33)$ & $31.7 v 22.3 p=0.03$ \\
\hline Tax initiative state $(n=4) \vee$ non-initiative state $(n=46)$ & $37.5 \vee 24.5 p=0.09$ \\
\hline Major tobacco grower status $(n=6) \vee$ minor $/$ non-grower states $(n=44)$ & $21.7 \vee 26.0 p=0.49$ \\
\hline Republican $(n=26) \vee$ Democrat $(n=24)$ control of state government & $25.9 \vee 25.1 p=0.85$ \\
\hline \multicolumn{2}{|c|}{$\begin{array}{l}\text { *Positive Spearman rank correlation coefficients indicate more TI/SAD lobbying expenditures as tobacco control indicators increase (for example, higher } \\
\text { taxes in } 1997 \text { is associated with higher TI spending). } \\
\text { †Ranks of TI/SAD lobbying expenditures are sorted in ascending order such that the higher rank average score indicates greater TI/SAD lobbying } \\
\text { expenditures compared to the lower score (for example, more TI spending in ASSIST compared to non-ASSIST states). } \\
\text { †Data for partisan control of state government in } 1996 \text { compared with TI/SAD state lobbying expenditures for } 1996 \text { only. } \\
\text { P Values are based on two sided statistical tests. Tobacco control measures showing significant association at the } 10 \% \text { level or higher are in bold type. } \\
\text { ASSIST, American Stop Smoking Intervention Study; SAD, State Activities Division; SOTC, strength of tobacco control; TI, Tobacco Institute. }\end{array}$} \\
\hline
\end{tabular}

smoking restrictions. ${ }^{37} 38$ Additionally, there are many documents indicating the TI, and the industry in general, counted upon organised labour to assist in fighting workplace smoking restrictions. ${ }^{39-44}$

There is evidence that these types of relationships did not always rely upon financial expenditures, ${ }^{45}{ }^{46}$ as indicated in a 1985 document from Philip Morris that advocated "making greater use of unions and organised labor" ${ }^{46}$ The document states the philosophy is to "try to identify groups that 'want something from us' and use these groups to our advantage. There are perhaps other groups who could be exploited." Such strategies would not be reflected in any budget. Other documents reflect the use of company programmes by lobbyists in the pursuit of legislative goals. For example, programmes such as the "Accommodation Program" were devised to prevent smoke-free air legislation, and "It's the Law" (developed by TI in the 1980s, and taken over by Philip Morris in the 1990s) was used to influence legislators on youth access issues. A 1995 memo from Philip Morris tells an employee "I want to get you more involved in what we have been doing to create 'model communities' with the AP [accommodation program] and the AF/ITL [Ask First/Its The Law] programs in Columbus and Cincinnati" ${ }^{47}$ It continues "all of this is being done to help Scott pass preemption legislation on the state level (for both accommodation and marketing) i.e. something positive to hold up to legislators." National programmes such as these would also not be reflected in lobbying specific categories in TI or company budgets.

Sales to minors laws proliferated in the 1980s and 1990s, in part because of the passage by the federal government of the Synar Amendment in 1992, which required states to enact and enforce such laws. ${ }^{17}$ PPU laws also proliferated in the 1990s. ${ }^{24} 25489$ Our results suggest that changes in sales to minors laws were not significantly associated with TI lobbying expenditures. This is not unexpected given the potentially deleterious impact upon the tobacco industry's image that opposition to youth access legislation would have. During the 1980 s the TI did develop youth tobacco prevention programmes conducted by the Public Affairs Division. ${ }^{50-53}$ In the 1990s, RJ Reynolds and Philip Morris also individually introduced prevention programmes to curb tobacco sales to minors. ${ }^{50}$ These programmes were of questionable efficacy and probably existed to augment industry public relations and lobbying efforts. ${ }^{47505253}$ However, in all cases these programmes were marketed nationally and were not funded under state and local lobbying budgets. The main opponents of stronger youth access laws have typically been organisations representing gas stations and convenience store owners, ${ }^{1}$ and the TI did support these types of trade associations. Finally, efforts to oppose youth tobacco access legislation may not draw the same lobbying attention as efforts to increase cigarette taxes since there is some question as to how effective sales to minors and PPU laws are in reducing smoking. ${ }^{24} 45$ 54-58 States that were strengthening PPU laws were significantly associated with TI lobbying expenditures. The tobacco industry has supported legislative efforts to criminalise minors' purchase, possession and use of tobacco products, which may explain the observed positive association between states strengthening of PPU laws and TI lobbying expenditures. ${ }^{44}$ Further research is needed to determine the extent and nature of industry lobbying for enactment of PPU laws.

A weakness of the use of TI specific budgets to evaluate the behaviour of the industry as a whole is the fact that the tobacco manufacturers funded organisations such as the NSA, independent of the TI. Additionally, most, if not all of the manufacturers directly employed lobbyists. Unfortunately, the budgetary information for these organisations is not itemised by state in any systematic manner. The NSA budgetary data exist in a less systematic fashion in public documents, but is not itemised by state. The TI did support state and local lobbying in all states in every year.

A basic underlying premise to any document based research is that we do not know what we do not have. In the case of the NSA, the loosely reported data do not provide a clear picture of funded activities. With the TI state and local budget data we were able to compile for this study, we believe we have tapped into a vein of consistently reported information on budgetary spending by the tobacco industry. Several examples exist which serve to support the findings of our analysis. A Philip Morris public affairs requested budget for $1994^{59}$ itemises by issue (that is, excise tax, smoking restrictions, etc), and this document clearly indicates that smoking restrictions and state level excise taxes received the bulk of attention, at least in financial terms. However, programmes such as "Project Alpha", to "respond to criticism of industry marketing practices" through "state and local officials and the press", and other youth issues received a small portion of the total 
budget laid out in this budgetary document. A document titled "Issues Management 950000 Budget" $^{\text {"60 }}$ follows the same format and includes the same categories-and contains a similar distribution of funding. Additionally, there is other material that describes the level of coordination between the companies and the TI in state and local lobbying efforts. ${ }^{61}$

The information we were able to acquire from the states tended to show that the TI budgets at least reflect the order of magnitude of fees paid, and correctly represent whom they were paid to. In some cases the data in the TI budgets actually helped to add clarity to the state's records. In most cases, the expenditures described in the TI budgets match very closely with the public records we were able to obtain. However, we did discover a few instances where these figures differ from what was publicly reported. For example, an Indiana lobbyist is listed as having \$42000 allocated to him in the $1997 \mathrm{TI}$ budget, but his total reported expenses on behalf of the TI was \$564.36, and his total reimbursement for that year from the TI

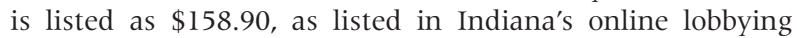
database. ${ }^{62}$ Another example of the lack of clarity in public reporting of lobbyist fees is the sum listed in the same budget for a Massachusetts lobbyist. The total listed for this individual is $\$ 78000$, according to the 1997 TI budget. The Massachusetts website containing lobbying data lists no expenditure from the TI to this individual in $1997 .{ }^{62}$ However, it lists the total TI expenditure in Massachusetts in 1997 as $\$ 35000$ to a firm that lists the individual as an employee. Also, the amounts listed within the TI budgets for individual states tend to stay relatively consistent year to year. Additionally, there are other state data that suggest the TI budgets provide us with accurate representations of spending. A Washington State lobbyist is listed in the 1997 TI budget as receiving $\$ 50000$ for 1996, and this corresponds exactly with his officially reported salary (an additional $\$ 8810.57$ was listed as being paid for "other lobbying expenses). ${ }^{62}$ We do not suggest that there was any impropriety in how the lobbyists reported data. However, examples such as these serve to underscore the inconsistent nature of publicly reported lobbying data at the state level.

It should be reiterated that the data we utilised from within the TI are limited. The lobbying variable was created from only $35 \%$ of the State Activities Budget, with large portions going to political contributions in many years. Also, the lack of consistently numbered expenditure categories for 1993 caused a temporal lapse in our data set. However, we are confident that while the TI budgets do not necessarily depict exact expenditures, they do offer a view of the shifts in expenditures over time and locale. We looked for a source of data that offered state-by-state data in a standardised way, and we did not find any. The methodology we employed offers an analysis of an internally consistent record of lobbying expenditures of the TI.

In summary, this paper presents a glimpse of TI budgets, which we believe are informative beyond the reliance on publicly and lawfully reported contributions and lobbying expenditures. It is impossible to know what expenditures remain outside the mechanism of the TI annual budgets. Despite this limitation we believe that the lobbying expenditures of the TI were part of an overall coordinated industry effort to oppose the most effective tobacco control strategies.

\section{ACKNOWLEDGMENTS}

The research described in this paper was supported by grants from the National Cancer Institute CA77021-03, CA87696-01, and by Core Grant CAl6056-26, as well as by Project ImpacTeen, funded by the Robert Wood Johnson Foundation, through the University of Chicago at Illinois (Frank Chaloupka, Principal Investigator). In addition, this work was also supported by National Cancer Institute contract No. N01-CP-95030. The content of this publication does not necessarily reflect the views or policies of the Department of Health and Human Services, nor does mention of trade names, commercial products, or organisation imply endorsement by the US government.

\section{What this paper adds}

The tobacco industry lobbies vigorously at all levels of government, including the state and local levels. Previous studies have documented variation in the level and substance of tobacco industry lobbying activity at the state and local levels of government. However, variation over time and between states in the reporting requirements of lobbyists and lobbyist employers has been an obstacle to studying how industry lobbying activity may have changed over time and between states.

This paper presents results of an analysis of data extracted from TI budgets from 1991 and 1997. We found significant associations between TI State Activities Division expenditures at the state and local level and cigarette excise tax levels, the status of a state as a recipient of federal ASSIST (American Stop Smoking Intervention Study) funds, and changes in the strength of statewide laws that penalise minors for possessing, purchasing, and/or using cigarettes. We found little or no association between state and local lobbying budgets of the TI and changes in statewide smoke-free air laws, or changes in the strength of states' sales to minors' laws. However, TI special projects expenditures were earmarked to specific states and localities involved with efforts to pass clean indoor air legislation/regulations (that is, Maryland and New York City). We also found evidence showing that special project expenditures increased in states considering tobacco tax increases (for example, Ohio, Colorado, Utah, Washington). Since ASSIST supported state programmes had as one of their main objectives enactment of smoke-free laws and higher cigarette taxes, it is not surprising that our analysis shows that these states also attracted the greatest lobbying attention from the TI.

\section{Authors' affiliations}

C P Morley, K M Cummings, A Hyland, G A Giovino, J K Horan, Department of Cancer Prevention, Epidemiology \& Biostatistics, Roswell Park Cancer Institute, Buffalo, New York, USA

\section{REFERENCES}

1 Givel MS, Glantz SA. Tobacco lobby political influence on US state legislatures in the 1990's. Tobacco Control 2001;10:124-34.

2 Galen EA, Hobart RL, Reed, DF. Overcoming a powerful tobacco lobby in enacting local smoking ordinances: the Contra Costa County experience. Journal of Public Health Policy 1996;17:28-46.

3 Traynor MP, Begay ME, Glantz SA. New tobacco industry strategy to prevent local tobacco control. JAMA 1993;270:479-86.

4 Goldstein AO, Bearman NS. State tobacco lobbyists and organizations in the United States: crossed lines. Am J Public Health 1996;86:1 137 42.

5 Aguinaga Bialous S, Glantz SA. Arizona's tobacco control initiative illustrates the need for continuing oversight by tobacco control advocates. Tobacco Control 1999;8:141-51.

6 Monardi F, O'Neill A, Glantz S. Tobacco industry political activity in Colorado. San Francisco: Institute for Health Policy Studies, University of California, San Francisco. May, 1996. http://galen.library.ucsf.edu/ tobacco/co/

7 Malone RE, Balbach ED. Tobacco industry documents: treasure trove or quagmire? Tobacco Control 2000;9:334-8

8 Tobacco Institute. The Tobacco Institute 1992 proposed budget. The Tobacco Institute. December 3, 1991. Bates range: 92757780-92757829. http://www.lorillarddocs.com

9 Tobacco Institute. The Tobacco Institute 1992 proposed budget. The Tobacco Institute. December 3, 1991. Bates range: 92757830-92757912. http://www.lorillarddocs.com

10 Tobacco Institute. The Tobacco Institute 1993 proposed budget. The Tobacco Institute. October 14, 1992. Bates range: 91085541-91085584. http://www.lorillarddocs.com

11 Tobacco Institute. The Tobacco Institute 1994 proposed budget. The Tobacco Institute. November 12, 1993. Bates range: 91082882-91082938. http://www.lorillarddocs.com

12 Tobacco Institute. The Tobacco Institute: 1995 proposed budget. The Tobacco Institute. November 3, 1994. Bates range: 91082768-91082808. http://www.lorillarddocs.com

13 Tobacco Institute. The Tobacco Institute 1995 proposed budget. The Tobacco Institute. November 3, 1994. Bates range: 91082809-91082879. http://www.lorillarddocs.com. 
14 Tobacco Institute. The Tobacco Institute 1995 proposed budget. The Tobacco Institute. November 3, 1994. Bates range: 91082768-91082813. http://www.lorillarddocs.com

15 Tobacco Institute. The Tobacco Institute 1996 budget. The Tobacco Institute. October 24, 1995. Bates range: TNWL 0004351-TNWL 0004380. http://www.tobaccoinstitute.com. No longer available on web site "due to clerical error".

16 Tobacco Institute. The Tobacco Institute 1996 budget. The Tobacco Institute. October 24, 1995. Bates range: $91891283-91891293$. http://www.lorillarddocs.com.

17 Tobacco Institute. The Tobacco Institute 1996 budget. The Tobacco Institute. December 12, 1996. Bates range: TNWL 0004430-TNWL 0004457. http://www.tobaccoinstitute.com. No longer available on web site "due to clerical error".

18 The Tobacco Institute. 1996 Tobacco Institute budget. The Tobacco Institute. October 27, 1995. Bates range: $2041212102-2041212216$. http://www.pmdocs.com.

19 Cherry JR. Memorandum entitled: "Tobacco Institute Budget." Lorillard Tobacco Company. September 29, 1994. Bates range: 92756025-92756026. http://www.lorillarddocs.com.

20 Cummings-Super CL. Letter from Michigan Distributors and Vendors Association, Inc. regarding Tobacco Institute's budget cuts. Michigan Distributors and Vendors Association, Inc. November 2, 1993. Bates range: $517125620-517125621$. http://www.rirtdocs.com.

21 Stillman F, Hartman A, Graubard B, et al. The American stop smoking intervention study. Conceptual framework and evaluation design. Eval Rev 1999;23:259-80.

22 Heiser PF, Begay ME. The campaign to raise the tobacco tax in Massachusetts. Am J Public Health 1997;87:968-73.

23 Aguinaga Bialous S, Macdonald $H$, Traynor $M$, et al. Undermining popular government: tobacco industry political expenditures in California 1993-1994. May 1995. http://www. library.ucsf.edu/tobacco/ undermining/

24 Goldman LK, Glantz SA. The passage and initial implementation of Oregon's Measure 44. Tobacco Control 1999:8:311-2.

25 Tobacco Institute. The tax burden on tobacco. Tobacco Institute Historical Compilation. Volume 33. Washington DC: The Tobacco Institute, 1998

26 National Cancer Institute. State and local legislative action to reduce tobacco use. Smoking and Tobacco Control Monograph No. 11 Bethesda, Maryland: US Department of Health and Human Services, National Institutes of Health, National Cancer Institute, NIH Publication No. 00-4804, August 2000: 29-30.

27 Giovino GA, Wakefield M. Chaloupka FJ, et al. Study of youth smoking and state laws prohibiting the purchase, possession, and/or use of cigarettes by minors - United States, 1991-1998. Paper presented at the 9 th annual meeting of the Society for Prevention Research. Washington DC; 1 June 2001

28 Schillings EM, Welch C, eds. State legislated actions on tobacco issues, 12 th ed. American Lung Association, 2000.

29 Centers for Disease Control and Prevention, Office on Smoking and Health, STATE (State Tobacco Activities Tracking and Evaluation) System: http://www2.cdc.gov/nccdphp/osh/state/

30 Alciati MH, Frosh M. Green SB, et al. State laws on youth access to tobacco in the United States: measuring their extensiveness with a new rating system. Tobacco Control 1998;7:345-52.

31 Economic Research Service/U.S. Department of Agriculture: http://www2.cdc.gov/nccdphp/osh/state/report index.htm.

32 Luke DA, Stamatakis KA, Brownson RC. State youth-access tobacco control policies and youth smoking behavior in the United States. Am J Prev Med 2000;19:180-7.

33 National Conference of State Legislatures Homepage at http://www.ncsl.org/. Note: The data we were able to obtain from this site no longer appears to be available to the general public.

34 Gilpin EA Stillman FA, Hartman AM, et al. Index for US state tobacco control initial outcomes. Am J Epidemiol 2000;152:727-38.

35 Shopland DP, Hartman AM, Repace JL, et al. Smoking behavior, workplace policies, and public opinion regarding smoking restrictions in Maryland. Maryland Med J 1995:44:99-104.

36 Clarke H, Wilson M, Hyland A, et al. Campaign to enact New York City's smoke-free air act. Journal of Public Health Management and Practice 1999;5:1-13.

37 NSA political plan outline. Philip Morris Incorporated. December 1993. Bates range: $2023203153-2023203158$. http:// www.pmdocs.com

38 Americans for Nonsmokers' Rights. The National Smokers Alliance: exposed - a report on the activities of Philip Morris' \# 1 front group. http://www.no-smoke.org/nsa.html
39 Tobacco Institute. Labor indoor air quality presentations and events 1988-1989. 1989. Bates range: $92760977-92760989$. http://www.lorillarddocs.com

40 Chilcote SD Jr. Public smoking issue. The Tobacco Institute. August 23, 1985. Bates range: $88115249-88115251$. http:// www.lorillarddocs.com

41 Dowling JM, Irish KM. Committee on smoking and health. Philip Morris Incorporated. July 1, 1986. Bates range: 2025857573-2025857574. http://www.pmdocs.com

42 Griffin Media Group. Enlisted organized labor in opposition to the proposed 'no smoking' legislation. Philip Morris Incorporated. July, 1986. Bates range: 2025857582-2025857583. http:// www.pmdocs.com.

43 Lattanzio T. WA OSHA update. Philip Morris Incorporated. February 18, 1994. Bates range: 2024199161 . http://www.pmdocs.com

44 Entering the term "PRO-ACTIVE PROPOSAL" into the Tobacco Institute Document web site search engine will yield a number of informative documents pertaining to this issue

45 Chilcote SD Jr. Workplace discrimination against smokers. The Tobacco Institute. February 21, 1986. Bates range: 2025853995. http://www.pmdocs.com

46 Outline for March 29, 1985 meeting on corporate affairs. Philip Morris Incorporated. March 20, 1985. Bates range: 2023268446-2023268448. http://www.pmdocs.com

47 Philip Morris Incorporated. Ohio. Philip Morris Co. Inc. January 1, 1995. Bates range: 2046093720. http://www.pmdocs.com

48 Difranza JR. Are the federal and state governments complying with the Synar Amendment? Arch Pediatr Adolesc Med 1999;153:1089-97.

49 Giovino GA, Smith MW, Tworek C, et al. The association between tobacco control legislation and state-specific tobacco use prevalence estimates. Poster presentation at the 7th annual meeting of the Society for Research on Nicotine and Tobacco; Seattle, Washington; March 23, 2001.

50 Cummings KM, Leavell NR. Is the tobacco industry really interested in preventing youth smoking? Presented at the American Public Health Association Annual Meeting, Chicago, Illinois, November 8, 1999.

51 Chilcote S. Concerning plans for promotion of responsible living program and "helping youth decide". The Tobacco Institute. March 10, 1986. Bates range: TIMN0050285. http://www.tobaccoinstitute.com

52 DiFranza JR, McFee T. The Tobacco Institute: helping youth say "yes" to tobacco. J Family Pract 1992;34:694-99.

53 Difranza JR, Brown L. The Tobacco Institute's "It's the Law" campaign: has it halted illegal sales of tobacco to children? Am J Public Health 1992;82:1271-3

54 Carol J. It's a good idea to criminalise purchase and possession of tobacco by minors - NOT! Tobacco Control 1992;1:296-7.

55 Cismoski J. Blinded by the light: the folly of tobacco possession laws against minors. Wisconsin Med J 1994;93:91-8.

56 Lynch BS, Bonnie RJ, eds. Growing up tobacco free: preventing nicotine addiction in children and youths. Washington: National Academy Press, 1994.

57 Mosher JF. The merchants, not the customers: resisting the alcohol and tobacco industries' strategy to blame young people for illegal alcohol and tobacco sales. Journal of Public Health Policy 1995; 16:412-32.

58 Wolfson M, Hourigan M. Unintended consequences and professional ethics: criminalization of alcohol and tobacco use by youth and young adults. Addiction 1997;92:1159-64.

59 Philip Morris Incorporated. Public affairs 1994 requested budget. Philip Morris Co. Inc. April 1994. Bates range: 2044700846-2044700855. http://www.pmdocs.com

60 Philip Morris Incorporated. Issues management 1995 budget. Philip Morris Co. Inc. October 1994. Bates range: 2047047460-2047047465. http://www.pmdocs.com

61 Philip Morris Incorporated. Assessment of PM, TI, and industry lobbyists - dealing with weaknesses. Philip Morris Incorporated. Undated. Bates range: 2023918710-202398714. http:// www.pmdocs.com.

62 See http://www.ai.or/ilrc/data/96endperwk3 2.html http://db.state.ma.us; and http://hera.pdc.wa.gov/wx/fieldsearch.asp for Indiana, Massachusetts, and Washington Lobbying data sources, respectively. Data for New York State was acquired from http://www.nylobby.state.ny.us and via mail. California lobbyist data was acquired from the California State Archive via mail after a telephone request. An excellent web meta-source for lobbying data, linking what is available for all 50 states, is hosted by the Federal Election Commission at http://www.fec.gov/pubrec/cfsdd.htm. 